\title{
PENGEMBANGAN PROGRAM PENDIDIKAN DI SD ISLAM INTERNASIONAL AL-ABIDIN SURAKARTA DALAM MENGHADAPI MEA
}

\author{
Tsabita Fiki Amalia ${ }^{1}$, Ika Candra Sayekti². \\ Prodi PGSD FKIP Universitas Muhammadiyah Surakarta \\ ${ }^{1}$ tsabitafiq@gmail.com, ${ }^{2}$ ics142@ums.ac.id
}

\begin{abstract}
ASEAN Economic Community (AEC) ia an integratied system of the countries in Southeast Asia that enable and facilitate the free trade system. Since 2015 the AEC has been officially started, and many foreign companies has been opened in Indonesia. However, the quality of Human Resources (HR) in Indonesia is lacking to confront AEC's system. It can be seen from the number of unemployed people in Indonesia and Indonesian citizen education level is still low. This shows a lack of quality in education. Departing from this problem, the authors conducted research at the international elementary school, SDII Al Abidin Surakarta. This school has excellent programs that can be developed and replicated in order to improve the quality of Human Resources (HR) since elementary school. This research aims to study programs that are run in order to deal with AEC. This research was conducted with a qualitative descriptive method by collecting data through interviews, observation, and documentation. The results showed some excellent programs that are owned by SDII Al Abidin Surakarta which can be used as a weapon to face the ASEAN Economic Community $(A E C)$. The programs are international curriculum, three varians grade programs, and extracurricular.
\end{abstract}

Keywords: program, international, $A E C$

\section{PENDAHULUAN}

Sejak satu dekade lalu, para pemimpin ASEAN sepakat membentuk sebuah pasar tunggal di kawasan Asia Tenggara pada akhir 2015. Ini dilakukan agar daya saing ASEAN meningkat dan menarik investasi asing serta bisa menyaingi Cina dan India. Pembentukan pasar tunggal yang diistilahkan dengan Masyarakat Ekonomi ASEAN (MEA) memungkinkan satu negara menjual barang dan jasa dengan mudah ke negara-negara lain di seluruh Asia Tenggara sehingga kompetisi akan semakin ketat.

Pelaksanaan MEA 2015 tidak lepas dari dampak positif dan negatif, namun jika dilihat dari tingkat pendapatan yang belum merata serta kesenjangannya dengan negara-negara yang maju di kawasan ASEAN lainnya. MEA 2015 justru memberikan peluang yang postif bagi pembangunan domestik maupun pengembangan internasional, dengan prosedur dan pengembangan profesionalitas yang jelas maka MEA akan mampu merubah tantangan menjadi peluang bagi pertumbuhan ekonomi Indonesia yang lebih baik.

Usaha peningkatan kualitas SDM dapat ditempuh dengan upaya sinergi antara pemerintah, pelaku usaha, dan akademisi untuk menetapkan standar kompetensi profesionalisme di masing-masing sektor. Upaya peningkatan kualitas SDM untuk bersaing dalam menghadapi MEA 2015 harus segera dilaksanakan dalam rangka mencapai kemajuan dan mengejar ketertinggalannya dari negara-negara lain. Produktivitas menjadi penopang utama daya saing suatu perekonomian namun faktor-faktor lainnya 
seperti kualitas infrastruktur, kualitas pendidikan, iklim investasi, kondisi transportasi, logistik, sistem perbankan yang probisnis serta faktor pendukung lainnya perlu ditingkatkan (BKF: 2014).

Pendidik merupakan tenaga profesional yang bertugas merencanakan dan melaksanakan proses pembelajaran, menilai hasil pembelajaran, melakukan pembimbingan dan pelatihan, serta melakukan penelitian dan pengabdian kepada masyarakat, terutama bagi pendidik pada perguruan tinggi (UU No. 20 tahun 2003 tentang Sisdiknas). Pendidik meliputi pendidik pada TK/RA, SD/MI, SMP/MTs, SMA/MA, SDLB/SMPLB/SMALB, SMK/MAK, satuan pendidikan Paket A, Paket B dan Paket C, dan pendidik pada lembaga kursus dan pelatihan.

Pendidik (guru) harus memiliki kualifikasi akademik dan kompetensi sebagai agen pembelajaran, sehat jasmani dan rohani, serta memiliki kemampuan untuk mewujudkan tujuan pendidikan nasional. Kualifikasi akademik yang dimaksudkan di atas adalah tingkat pendidikan minimal yang harus dipenuhi oleh seorang pendidik yang dibuktikan dengan ijazah dan/atau sertifikat keahlian yang relevan sesuai ketentuan perundang-undangan yang berlaku.

Kompetensi sebagai agen pembelajaran pada jenjang pendidikan dasar dan menengah serta pendidikan anak usia dini meliputi: (a) kompetensi paedagogik, yaitu kemampuan pemahaman terhadap peserta didik, perancangan dan pelaksanaan pembelajaran, evaluasi hasil belajar, dan pengembangan peserta didik untuk mengaktualisasikan berbagai potensi yang dimilikinya; (b) kompetensi kepribadian, yaitu kemampuan personal yang mencerminkan kepribadian yang mantap, stabil, dewasa, arif dan berwibawa, menjadi teladan bagi peserta didik, dan berakhlak mulia; (c) kompetensi profesional. Yaitu penguasaan materi pembelajaran secara luas dan mendalam, yang mencakup penguasaan materi kurikulum mata pelajaran di sekolah dan substansi keilmuan yang menaungi materinya, serta penguasaan terhadap struktur dan metodologi keilmuannya.; dan (d) kompetensi sosial, yaitu kemampuan guru untuk berkomunikasi dan bergaul secara efektif dengan peserta didik, tenaga kependidikan, orang tua/wali peserta didik, dan masyarakat sekitar.

Tenaga kependidikan adalah anggota masyarakat yang mengabdikan diri dan diangkat untuk menunjang penyelenggaraan pendidikan. Tenaga kependidikan bertugas melaksanakan administrasi, pengelolaan, pengembangan, pengawasan, dan pelayanan teknis untuk menunjang proses pendidikan pada satuan pendidikan. Tenaga kependidikan meliputi: kepala satuan pendidikan; pendidik; dan tenaga kependidikan lainnya seperti wakil / kepala urusan, laboran, dan tata usaha.

Standar nasional pendidikan adalah kriteria mimimal tentang sistem pendidikan di seluruh wilayah hukum Negara Kesatuan Republik Indonesia. Untuk meningkatkan mutu dan kualitas pendidikan di Indonesia, pemerintah menentapkan 8 Standar Nasional Pendidikan (SNP) berdasarkan PP No. 32 Tahun 2013. Dalam hal ini 8 Standar Nasional Pendidikan yaitu : Standar isi; Standar proses; Standar kompetensi lulusan; Standar pendidik dan tenaga kependidikan; Standar sarana dan prasarana; Standar pengelolaan; g. Standar pembiayaan; $h$. Standar penilaian pendidikan 
(PP No 32 Tahun 2013 tentang Standar Nasional Pendidikan).

Standar Pendidik dan Tenaga Kependidikan adalah kriteria mengenai pendidikan prajabatan dan kelayakan maupun mental, serta pendidikan dalam jabatan. Pendidik harus memiliki kualifikasi akademik dan kompetensi sebagai agen pembelajaran, sehat jasmani dan rohani, serta memiliki kemampuan untuk mewujudkan tujuan pendidikan nasional. Kualifikasi akademik yang dimaksud adalah tingkat pendidikan minimal yang harus dipenuhi oleh seorang pendidik yang dibuktikan dengan ijazah dan/atau sertifikat keahlian yang relevan sesuai ketentuan perundangundangan yang berlaku. Seseorang yang tidak memiliki ijazah dan/atau sertifikat keahlian tetapi memiliki keahlian khusus yang diakui dan diperlukan dapat diangkat menjadi pendidik setelah melewati uji kelayakan dan kesetaraan.

Kualifikasi untuk guru SD/MI adalah minimal memiliki ijazah D-IV atau Sarjana dari bidang pendidikan SD/MI, bidang kependidikan lain, atau psikologi, dan memiliki sertifikat profesi guru untuk SD/MI. Pendidik pada SD/MI sekurang-kurangnya terdiri atas guru kelas dan guru mata pelajaran yang penugasannya ditetapkan oleh masingmasing satuan pendidikan sesuai dengan keperluan.

Sedangkan kualifikasi tenaga kependidikan di SD harus ada diantaranya: kepala sekolah; tenaga administrasi; tenaga perpustakaan; dan tenaga kebersihan. Untuk menjadi kepala sekolah SD/MI harus berstatus guur SD/MI dan memiliki pengalaman mengajar di SD/Mi minimal 5 tahun.
Selain itu, kepala sekolah juga harus memiliki kualifikasi akademik dan kompetensi sebagai agen pembelajaran sesuai ketentuan perundang-undangan yang berlaku, dan memiliki kemampuan kepimpinanan kewirausahaan di bidang pendidikan. Tujuan dari penelitian ini adalah untuk mengetahui dan menjelaskan program yang dilakukan di SDII Al-Abidin Surakarta dalam menghadapi MEA.

\section{METODE PENELITIAN}

Subjek penelitian yang digunakan dalam penelitian ini adalah guru, kepala sekolah, dan siswa SDII Al-Abidin Surakarta. Penelitian dilaksanakan di SDII Al-Abidin Surakarta selama 5 bulan.

Jenis penelitian yang digunakan adalah kualitatif deskriptif. Penelitian kualitatif menghasilkan deskripsi analitik tentang fenomena-fenomena secara murni bersifat informatif dan berguna bagi masyarakat peneliti, pembaca dan juga partisipan (Sukmadinata, 2007: 107). Sedangkan penelitian deskriptif pada umumnya dikumpulkan melalui dokumentasi, wawancara dan observasi.

Pengumpulan data yang diterapkan sebagai alat pengumpulan data dalam penelitian ini adalah:

\section{Observasi}

Pengamatan (Observasi) adalah metode pengumpulan data di mana peneliti atau kolaboratornya mencatat informasi sebagaimana yang mereka saksikan selama penelitian. Penyaksian terhadap peristiwa peristiwa itu bisa dengan mengamati atau melihat, mendengarkan, merasakan, kemudian dicatat seobjektif mungkin (Gulo, W. 2002: 116). Observasi dilakukan di SDII 
Al-Abidin Surakarta saat jam pelajaran berlangsung, dan saat ekstrakulikuler. observasi juga dilakukan di dalam maupun di luar kelas.

\section{Wawancara}

Wawancara merupakan pertemuan dua orang untuk bertukar informasi dan ide melalui tanya jawab, sehingga dapat dikonstruksikan makna dalam suatu topik tertentu (Esterberg, dalam Sugiyono 2012:233). Pada penelitian ini wawancara dilaksanakan dengan responden guru kelas, kepala sekolah, dan siswa. Wawancara dilakukan untuk mengetahui program yang dilaksanakan oleh SDII Al Abidin Surakarta dalam menghadapi MEA.

\section{Metode Dokumentasi}

Metode dokumentasi digunakan untuk mendapatkan data yang berupa portopolio, arsip, rekaman, dan laporan siswa (Suparno, paul. 2008: 58). Dalam dokumentasi ini digunakan untuk mengabadikan hasil - hasil penelitian untuk memperlancar proses pembuatan laporan. Teknik analisis data kualitatif menggunakan konsep yang diberikan Miles and Hubermen. Miles dan Hubermen dalam Sugiyono (2005: 91), mengemukakan bahwa aktivitas dalam analisis data kualitatif dilakukan secara interaktif dan berlangsung secara terus menerus sampai tuntas, sehingga datanya sudah jenuh. Aktivitas dalam analisis data yaitu data reduction, data display, dan conclution drawing/verivication.

Analisis data penelitian ini diawali pengumpulan data yang diperoleh dari observasi dan wawancara. Data yang diperoleh dari observasi dan wawancara kemudian direduksi untuk dirangkum. Data yang dihasilkan dapat diambil memalui metode kualitatif yang menghasilkan data deskriptif. Setelah data direduksi maka data dapat didisplay secara tersusun dalam pola hubungan. Kemudian menarik kesimpulan pada data yang telah didisplay. Jadi melalui teknik inilah dapat diketahui sejauh mana program pendidikan di SDII Al-Abidin dalam menghadapi MEA.

Setelah data dianalisis dan dilakukan penafsiran, maka hasil penelitian dapat disimpulkan. Penarikan kesimpulan program yang dilakukan SDII Al-Abidin Surakarta dalam menghadapi MEA berdasarkan kenyataan yang ada di lapangan.

\section{HASIL DAN PEMBAHASAN}

SDII Al-Abidin Surakarta merupakan salah satu sekolah bertaraf internasional di kawasan Surakarta. Taraf internasional tersebut sudah jelas terlihat bahwa SDII AlAbidin memiliki cita-cita untuk Go International. Tidak hanya menawarkan nama yang bergengsi, SDII Al-Abidin memiliki beberapa beberapa program unggulan yang merupakan senjata menghadapi Masyarakat Ekonomi ASEAN (MEA).

Program yang pertama adalah adanya 3 jenis kelas yang berbeda. Kelas yang dimiliki oleh SDII Al-Abdidin surakarta terbagi 3 jurusan yaitu Tahfidz Class Program, Bilingual Class Program, dan International Class Program. Masing-masing kelas tersebut memiliki kelebihan masing masing. Tahfidz Class Program diperuntukkan bagi siswa yang berminat untuk menghafal al-quran. Bilingual Class Program merupakan kelas dengan pembelajaran biasa dengan dua bahasa pengantar, yaitu bahasa Indonesia dan Inggris. Sedangkan International Class 
Program adalah kelas internasional yang menggunakan kurikulum Cambridge.

Program pertama yaitu kurikulum yang digunakan oleh SDII Al-Abidin Surakarta tidak hanya berasal dari satu kurikulum saja. Terdapat 3 macam kurikulum yang digunakan, yaitu Kurikulum 2013 yang berasal dari dinas; Kurikulum Cambridge yang digunakan untuk mendukung visi dan misi sekolah yang bernamakan international; dan kurikulum yang mendukung lainnya untuk menjadikan SD II Al-Abidin menjadikan sekolah islam international yaitru kurikulum Jaringan Sekolah Islam Terpadu (JSIT).

Program yang kedua adalah adanya 3 jenis kelas yang berbeda. Kelas yang dimiliki oleh SDII Al-Abdidin Surakarta terbagi 3 jurusan yaitu Tahfidz Class Program; Billingual Class Program, dan International Class Program. Masing-masing kelas tersebut memiliki kelebihan masing masing.

Tahfidz Class Program diperuntukkan bagi siswa yang berminat untuk menghafal alquran. Pembelajaran di kelas ini menggunakan paduan antara kurikulum 2013, dan kurikulum JSIT. Tahfidz merupakan program hafalan al-quran dengan target hafalan 3-5 juz. Melalui progam kelas ini, siswa bisa tetap belajar sesuai dengan kurikulum pemerintah sambil menghafal alquran.

Billingual Class Program merupakan kelas dengan pembelajaran paduan antara kurikulum 2013 dan kurikulum JSIT dengan dua bahasa pengantar, yaitu bahasa Indonesia dan Inggris. Sebagian besar pembelajaran menggunakan kombinasi 2 bahasa tersebut. Hal ini dilakukan untuk membiasakan anak dengan bahasa Inggris yang merupakan bahasa dunia sehingga anak dapat terbiasa mendengar dan berbicara dengan bahasa Inggris, sehingga dimasa depan anak tidak akan kesulitan apabila bertemu dengan warga negara asing atau berada di negara lain.

Sedangkan International Class Program adalah kelas internasional yang menggunakan paduan kurikulum Cambridge, Kurikulum 2013, dan kurikulum JSIT. Dalam pembelajaran juga diberlakukan bilingual, atau 2 bahasa. Yaitu bahasa Inggris dan bahasa Indonesia. Maksud dan tujuannya sama, yaitu untuk mempersiapkan anak di masadepan dalam menghadapi MEA.

Siswa tidak menempuh tes tertentu untuk memasuki kelas mana yang harus ditempuh. Namun, orangtua siswalah yang berperan karena setiap orangtua paham betul kemampuan anaknya dan orangtua tidak akan memaksa anak masuk ke kelas yang di atas kemampuan anak. Setelah penjurusan kelas, dilakukan observasi terhadap siswa. Siswa yang tidak mampu mengikuti pelajaran di kelas akan dipindahkan ke kelas yang lain namun harus dengan persetujuan orangtua.

Program yang ketiga yaitu ekstrakulikuler. Pada kegiatan ekstrakulikuler tersebut siswa diajak untuk siap dalam menghadapi MEA. Siap bukan hanya kata, tapi juga lewat perbuatan, dengan dipersiapkan secara matang dan bisa terjun dalam segala lini. Ekstrakulikuler di SDII Al abidin Surakarta tidak hanya pramuka atau ekstrakulikuler yang popular di sekolah lain. Ekstrakulikuler di SDII Al-Abidin Surakarta sangat bervariasi, antara lain: Memanah; karate; taekwondo; tapak suci; Bahasa Jepang; Bahasa Mandarin; Bahasa Inggris; robotik; science terapan; science modern; music; vocal; dan masih banyak lagi.

Siswa bebas memilih ekstrakulikuler sesuai dengan minat siswa. Tidak hanya 
dilihat dari minat siswa, guru yang melihat potensi siswa juga boleh merekomendasikan ke siswa dan orangtua siswa. Sehingga bakat dan minat siswa dapat dikembangkan dengan baik melalui ekstrakulikuler yang ada.

SDII Al-Abidin sadar betul bahwa siswasiswinya perlu belajar melalui ekstrakulikuler dengan sungguh-sungguh. Guru/pengajar yang disediakan untuk mengajarkan ekstrakulikuler berasal dari dalam/luar sekolah yang ahli dibidangnya. Dalam hal ini, SDII Al-Abidin juga banyak menggandeng lembaga non akademik dalam mengajar ekstrakulikuler, seperti ahli dari sekolah robotic, atlet panahan, dll. Dengan adanya pengajar ahli ini, diharapkan dapat memotivasi dan mengembangkan bakat dan minat siswa.

Pada pembelajaran siswa juga dipersiapkan untuk MEA, siswa dikenalkan berbagai macam suku bangsa, warna kulit, nama bangsa \& negara, kultur negara lain, dll. Bukan hanya secara umum, namun diperkenalkan melalui pembelajaran. Contoh sederhananya, dalam penggunaan nama, guru mengenalkan nama bukan hanya nama Indonesia, seperti, Brian, Michele, Omar, dan Syafii. Pengenalan tersebut dimaksudkan siswa tidak hanya mengetahui nama orang Indonesia saja, namun siswa juga mengetahui asal negara mereka dengan mengetahui namanya.

Kegiatan lainnya yaitu kegiatan kewirausahaan yang dilaksanakan oleh siswa. Pada hari tertentu siswa diminta membawa barang atau makanan untuk dijajakan di depan kelas. Kegiatan ini dapat melatih kepercayaan diri, hemat, jujur dan bertanggung jawab. Hal ini juga dapat mengajak siswa lebih siap di era MEA.

\section{SIMPULAN}

SDII Al-Abidin turut serta mempersiapkan sumber daya manusia yang berkualitas sejak bangku sekolah dasar. Melalui beberapa program unggulannya, siswa diharapkan dapat bersaing dalam dunia MEA di masa depan.

Program yang dilakukan SDII Al-Abidin antara lain, yaitu: (1) Variasi kurikulum, yaitu dengan tambahan kurikulum Cambridge yang diterapkan di sekolah; (2) Variasi bahasa, seperti bahasa Inggris, Jepang, dan Mandarin; (3) Variasi jenis kelas, yaitu Tahfidz Class Program, Billingual Class Program, dan International Class Program; (4) Variasi ekstrakulikuler, yaitu robotik, science modern, science terapan, panahan, dll.

\section{DAFTAR PUSTAKA}

BKF. 2014. "Analisa Daya Saing dan Produktivitas Indonesia Menghadapi MEA”. Riset Kajian Badan Kebijakan Fiskal Pusat Kebijakan Regional dan Birateral Kementerian Keuangan Republik Indonesia. http://kemenkeu.go.id (diunduh 20 Januari 2016)

Gulo, W. 2002. Metodologi Penelitian. Jakarta: Gramedia Widiasarana Indonesia.

Peraturan Pemerintah Nomor. 32 Tahun 2013 tentang Standar Nasional Pendidikan 
Standar Nasional Pendidikan (SNP) berdasarkan PP No. 32 Tahun 2013

Sugiyono.2012. Metode Penelitian Kuantitatatif Kualitatif Dan R \& D. Bandung. Alfa Beta Bandung

Sukmadinata, Nana Syaodih. 2007. Metode Penelitian Pendidikan. Bandung: Rosdakarya.

Suparno, Paul. 2008. Action Research Riset Tindakan untuk Pendidik. Jakarta: Grasindo

Undang-undang Nomor. 20 Tahun 2003 tentang Sistem Pendidikan Nasional. 